\title{
THE PLANKTON IN THE UPPER REACHES OF THE BRISTOL CHANNEL
}

\author{
By Colin B. Rees, B.Sc. \\ University College of Hull Oceanographic Laboratory, Leith
}

(Text-figs. I-I3)

\begin{tabular}{|c|c|c|c|c|c|c|c|}
\hline \multicolumn{8}{|c|}{ CONTENTS } \\
\hline Introduction & . & $\cdot$ & . & . & $\cdot$ & & 397 \\
\hline The Station & . & $\cdot$ & . & . & . & . & 398 \\
\hline The physical and & $\mathrm{d} \mathrm{ch}$ & $\mathrm{mi}$ & $\mathrm{f}$ & ors & . & . & 400 \\
\hline Salinity . & $0^{\circ}$ & . & . & . & . & . & 400 \\
\hline Temperature & & . & . & . & . & . & 402 \\
\hline$p \mathrm{H}$ & . & . & . & . & . & & 402 \\
\hline Phosphates & . & . & . & . & . & . & 402 \\
\hline Dissolved oxy & ygen & . & . & . & . & . & 403 \\
\hline Opacity & . & . & . & . & . & . & 403 \\
\hline The bacteria & . & . & . & . & . & . & 404 \\
\hline The plankton & . & - & . & . & . & . & 405 \\
\hline Diatoms & . & 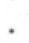 & . & . & . & . & 406 \\
\hline Copepods & . & . & . & . & . & . & $4 \mathrm{II}$ \\
\hline Other organisr & $\mathrm{sms}$ & - & . & . & . & . & 415 \\
\hline Discussion & . & . & - & . & . & . & 415 \\
\hline Acknowledgemer & ents & . & . & . & & . & 423 \\
\hline Summary . & . & . & . & . & ${ }^{\circ}$ & . & 423 \\
\hline References & . & . & . & . & . & & 424 \\
\hline
\end{tabular}

\section{INTRODUCTION}

The work embodied in this report was aimed, in conjunction with shore work, at determining the causes of the poverty of the marine fauna and flora in the Cardiff area. The plankton observations were made at a station which was visited 36 times between September 6 I936 and August 25 I937, with an unavoidable absence of visits in October. In addition some results obtained in September 1937 are used.

In so far as the area can be considered as estuarine, this work serves to fill a gap in annual quantitative data for British estuaries. Meek (1923a) has dealt with some isolated tow-nettings from the Tyne estuary and, later, Jorgensen (1929) made a more intensive investigation in the same estuary, but did not begin observations until May, thus missing the winter and spring conditions. The Tees survey (Alexander, Southgate \& Bassindale, 1935) included counts of Eurytemora, marine copepods and Coscinodiscus, but variations throughout the year are not noted. Wells (1938) investigated the 
plankton of the Thames estuary over a number of years. This work, also, was mainly qualitative.

Area I2 of the plankton survey, from I902 to I908, of the International Council (Ostenfeld, I93I) was concerned with the Bristol Channel, but the investigations were conducted well outside the present area.

\section{The Station}

Although it was presumed that the channel in the vicinity of Cardiff had estuarine characteristics, it was decided to restrict observations to one station, and the Cardiff Roads, shown in Fig. I, was selected. This was largely a matter of convenience, since work was done from a hired motor boat moored at the mouth of the river Ely, and the Cardiff Roads is the nearest place where the depth at high water exceeds 5 fathoms. The position is also sheltered from the prevailing westerly winds so that surface conditions are usually suitable for working there. Since, however, the boat was moored at the mouth of the river, it was very inconvenient to approach the station at low water, and it was owing to this difficulty that the low-water observations are so scanty. This work, therefore, is mainly concerned with high-water conditions.

The Cardiff Roads are about $\mathrm{I}_{4} \frac{1}{4}$ miles from the coast, 2 miles from the mouth of the nearest river, the Ely, over $2 \frac{1}{2}$ miles from the mouth of the Taff, and 4 miles from the Rhymney. From a width of 13 miles across at Barry, the Bristol Channel suddenly narrows to 8 miles across at the level of the station, and retains this width until near Newport. From Newport there is a further narrowing to the Severn river.

On the up-channel side of the station there is an entry of a large bulk of fresh water derived from the watersheds of the three rivers close to the station, the more distant rivers, the Usk, Wye, Severn, Avon, and a number of smaller rivers. This implies that the station is placed in a buffer area between the sea water of down-channel and the fresh water entering on the up-channel side. Much of the biology of the plankton is dependent on this fact and the relative effect of these bodies of water.

To the narrowing of the channel must be attributed the speed of the tidal streams. At spring tides the stream moves at a normal maximum of $4 \frac{1}{2}$ knots in the centre of the channel but may reach higher speeds, and, at neap tides, about 2 knots. The narrowing also affects the height of the tide, causing a spring rise for Penarth, which is probably closely comparable to the station, of $37 \frac{3}{4} \mathrm{ft}$., and a neap rise of $27 \frac{3}{4} \mathrm{ft}$. Tide tables are published in nautical almanacs giving the height of the tide for Penarth, and these values have been used in considering the results obtained.

Since the speed of the tidal streams decreases from the centre of the channel to the coast, no figures can be given for the speeds affecting the investigated area. If, however, we allow that the maximum speed of the tidal stream in the investigated area at neap tide is I knot, then the total drift 
of water within the tidal stream that forms a high tide at the station is 3.86 nautical miles. At spring tide, with a presumed maximum of $2 \frac{1}{2}$ knots, the

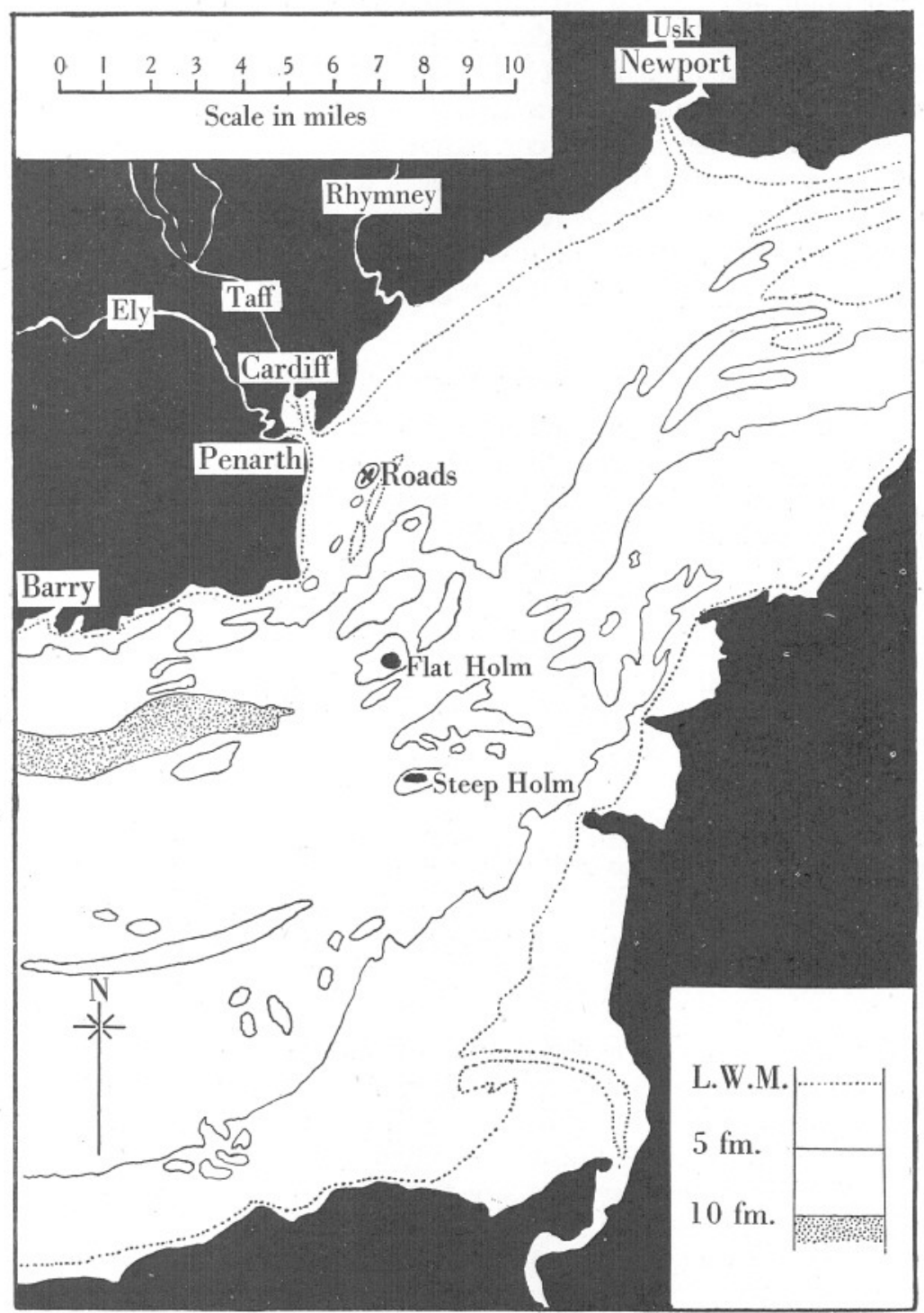

Fig. I. The upper reaches of the Bristol Channel. The station worked is marked $\times$.

total drift is $9 \cdot 66$ nautical miles, giving a difference of approximately 6 miles. With speeds of $\mathrm{I}$ and 2 knots the difference is about 4 miles. Since observations were made at the station at various phases of the tide, the records on 
different occasions refer, in reality, not to one point, but to a series of points along a length of channel of the order of about 4 miles. On any occasion, the particular point investigated can be defined in relation to the points on other occasions by the height of the tide, i.e. the higher the tide the farther downchannel is the point from which water has come to form a high tide at the station. Having recognized this meaning of height of tide, it becomes clear that a factor which has a direct correlation with the height of the tide must have an increasing value from up-channel to down-channel, and a factor with an inverse correlation must have a decreasing value. These remarks should render what follows more readily explicable.

A number of soundings at the station gave an average depth of about $13 \mathrm{~m}$.

\section{The Physical and Chemical Factors}

Coincident with the tow-nettings, water samples were taken at the station, transferred in pressure bottles to the laboratory, and analysed within 2 or $3 \mathrm{hr}$. of collecting. Table I gives the average values of some factors for each month for the surface water at high tide.

Table I. Average Values per Month of High-Tide SURFACE WATER

\begin{tabular}{|c|c|c|c|c|c|c|}
\hline Month & $\begin{array}{c}\text { No. of } \\
\text { samples }\end{array}$ & $\underset{0 / 00}{\text { Salinity }}$ & $p \mathrm{H}$ & $\begin{array}{l}\mathrm{P}_{2} \mathrm{O}_{5} \mathrm{mg} . \\
\text { per m. }\end{array}$ & $\begin{array}{l}\text { Dissolved } \\
\text { oxygen } \\
\text { c.c. }\end{array}$ & $\begin{array}{l}\text { Temp. } \\
\text { of water } \\
{ }^{\circ} \mathrm{C} \text {. }\end{array}$ \\
\hline Sept. & 3 & $27 \cdot \mathrm{I}$ & $8 \cdot 10$ & 69 & $5.5 \mathrm{I}$ & $17 \cdot 6$ \\
\hline Nov. & 2 & $26 \cdot 3$ & $7 \cdot 85$ & 85 & 5.76 & IO. I \\
\hline Dec. & 2 & 25.8 & 7.90 & 72 & $6 \cdot 66$ & $7 \cdot 7$ \\
\hline Jan. & 3 & $22 \cdot 5$ & $7 \cdot 95$ & 55 & $7 \cdot 13$ & $7 \cdot 4$ \\
\hline Feb. & 2 & $22 \cdot 3$ & $7 \cdot 80$ & 54 & $7 \cdot 47$ & 6.4 \\
\hline March & 4 & $22 \cdot 9$ & 8.00 & 33 & $7 \cdot 19$ & 5.8 \\
\hline April & 3 & $25 \cdot 4$ & $7 \cdot 95$ & 44 & 6.70 & 9.0 \\
\hline May & 4 & $25 \cdot 2$ & 8.00 & 35 & $6 \cdot 2 \mathrm{I}$ & 13.0 \\
\hline June & 5 & $26 \cdot 3$ & 8.05 & 33 & 5.80 & $16 \cdot 0$ \\
\hline July & 5 & $27 \cdot 3$ & 8.05 & 36 & $5 \cdot 36$ & $17 \cdot \mathrm{I}$ \\
\hline Aug. & 3 & 27.8 & $8 \cdot 10$ & 36 & 5.36 & 18.9 \\
\hline
\end{tabular}

Salinity. The salinity was determined by titration with silver nitrate.

The average salinity values (Table I) show a steady decrease from September to a minimum in February, followed by a steady rise, except for a slight deviation in May, up to August. This change in salinity demonstrates the effect of the fresh water coming down from the rivers, an effect which must be cumulative and persistent over a period of time.

The minimum value of $19.8 \%$ was obtained on January 25 , and the maximum of $28.0 \%$ on August 25. Fig. 2 shows the changes in value throughout the year. This curve, compared with the curve for the height of tide, shows a well-marked direct correlation between the two factors. That such a correlation exists implies that the bulk of fresh water entering the channel is slow, as well as cumulative, in effect, otherwise variations in rainfall between two successive samples would disturb the correlation. 


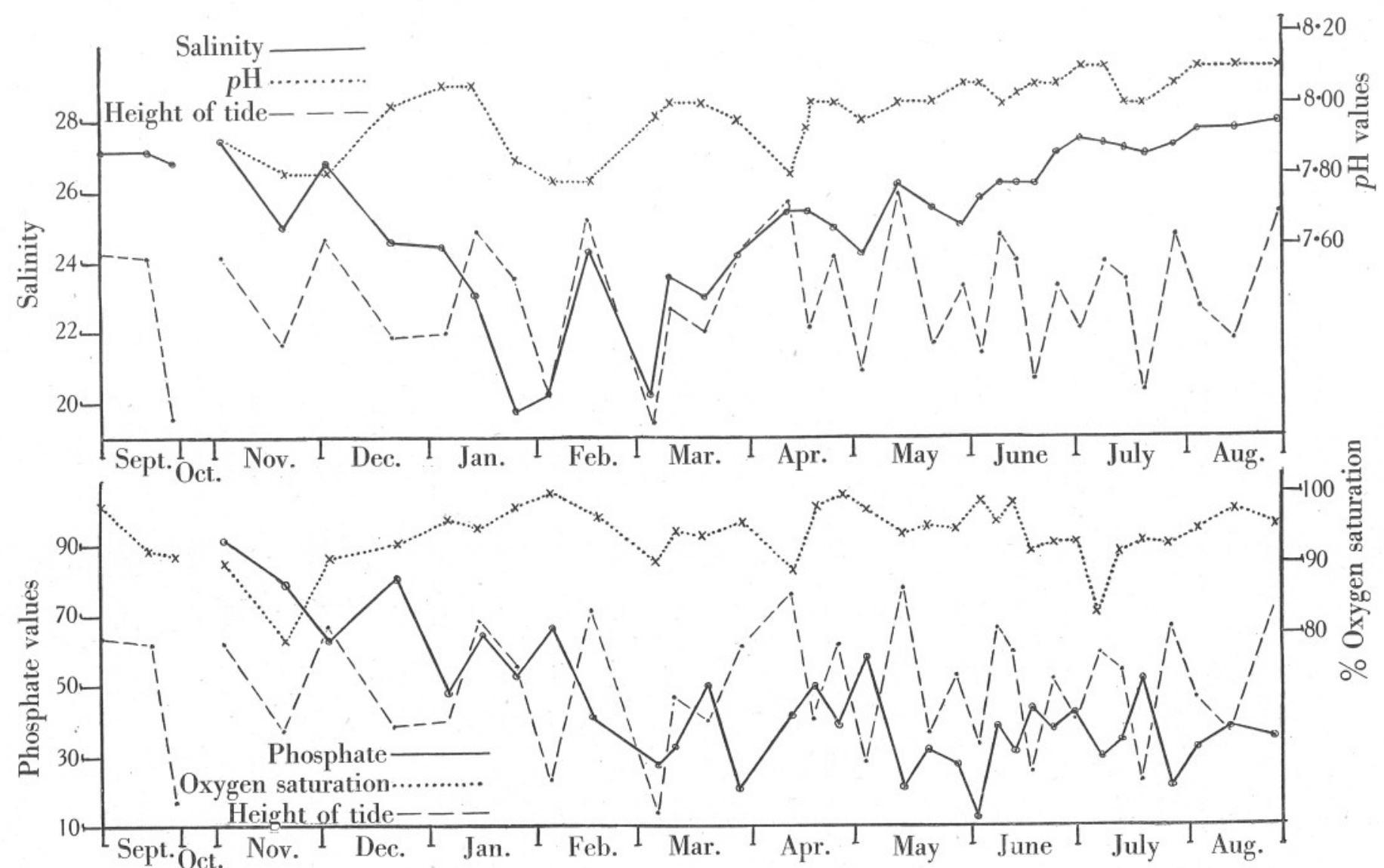

Fig. 2. The relation between the height of tide and the values of salinity, $p \mathrm{H}$, percentage oxygen saturation and phosphate for samples taken at the surface at high water. 
Water samples were taken on several occasions at various depths from the surface to the bottom by means of the Matthew's Fishery Water Bottle.* Except for one occasion there was no gradient in salinity. The exception was on July 27 (Table II), but this stratification was probably the result of the very heavy rain that fell over a wide area on July I5. A comparison of the weekly rainfall at Ross-on-Wye (Meteorological Office Report, Weekly Weather Records) with the changes in salinity suggests that the rainfall in the Wye and Severn catchment areas is effective at the station some I0-I4 days after the fall.

\section{Table II. Salinities \% $\% 0$ and Surface Temperature on July 27}

High water: I0.20 a.m., I0.23 p.m.; low water: 4.15 p.m.

\begin{tabular}{|c|c|c|c|c|c|c|}
\hline Time & I0.20 a.m. & I.5 p.m. & 4.20 p.m. & 6.15 p.m. & 7.0 p.m. & Io.ro p.m. \\
\hline Surface & $27 \cdot 3$ & $26 \cdot 7$ & $25 \cdot 6$ & $26 \cdot 5$ & $27 \cdot 2$ & $27 \cdot 4$ \\
\hline $4 \mathrm{~m}$. & $27 \cdot 6$ & $26 \cdot 8$ & 25.9 & .. & . & 28.0 \\
\hline $8 \mathrm{~m}$. & $28 \cdot 0$ & .. & 25.9 & .. & .. & $28 \cdot 2$ \\
\hline $12 \mathrm{~m}$. & $28 \cdot 0$ & 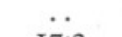 & $\ddot{*}$ & . & $\ddot{6}$ & $28 \cdot 3$ \\
\hline Temp. ${ }^{\circ} \mathrm{C}$. & 17.5 & $17 \cdot 2$ & 17.0 & $17 \cdot 0$ & 16.9 & $16 \cdot 8$ \\
\hline
\end{tabular}

Temperature. The temperature readings are correct to $0 \cdot \mathrm{I}^{\circ} \mathrm{C}$. The determined annual range was from $5.2^{\circ} \mathrm{C}$. on March Io to $19.3^{\circ} \mathrm{C}$. on August I3. Diurnal variations were small. Table II gives the variation with time and state of tide on July 27. Since this day was colder than the average for the month this range is probably greater than normal.

$\mathrm{pH}$. The $p \mathrm{H}$ was determined by McClendon's (19I7) method with cresol red as indicator.

Since it was found too inconvenient to evaluate the $p \mathrm{H}$ of the sample immediately, the delay of at least I hr. may have caused a change in the value. In addition to this, the salinity varied substantially from time to time, so that readings were made and corrected to an accuracy of $p \mathrm{H} 0.05$ only.

The values ranged from $p \mathrm{H} 8 \cdot \mathrm{I}$, which is comparable to normal sea water, to $p \mathrm{H} 7 \cdot 80$. Table I makes it clear that the $p \mathrm{H}$ change did not follow the salinity change, although the maximum and minimum average values of both occurred in the same month. The change from time to time, as shown in Fig. 2, was erratic, and, unlike the other three factors in this figure, bears no relation to the height of the tide. It is, however, possible that this lack of correlation, over short periods of time, is due to the degree of accuracy being insufficiently fine.

Phosphates. The phosphates were estimated by Atkins' (I923) modification of Denigès' method and the values calculated to milligrams of $\mathrm{P}_{2} \mathrm{O}_{5}$ per cu. $\mathrm{m}$.

Table I shows that the phosphate values were high up to February, dropped suddenly to $33 \mathrm{mg}$. in March, and remained about this level until the end of the period. Some of the phosphate that enters the channel as sewage may be precipitated as ferric phosphate. The mud at low water between the Rhymney and Newport contains $4-5 \%$ of iron in its dry weight.

* I am indebted to the authorities of the Plymouth Marine Laboratory for the loan of his instrument. 
The determined range was from $90 \mathrm{mg}$. per cu. m. on November 3 to I $2 \mathrm{mg}$. on June 3. Fig. 2 shows the changes throughout the year and further shows that these changes have an inverse correlation with the height of the tide. At the beginning of the period the inverse correlation is not good, but this is probably due to the greater intervals between successive samples during this period. From February onwards the inverse correlation is good, the biggest deviation being the lowest value of $\mathrm{I} 2 \mathrm{mg}$. on June 3 .

The values given in Table III for the change of phosphate value with the state of the tide on July 27 show that there was a higher concentration of phosphate at low water than at high water.

\section{Table III. Changes of Phosphate and Oxygen Saturation With State of Tide ON July 27}

$\begin{array}{lccc} & \text { High water } & \text { Low water } & \text { High water } \\ \text { Phosphate } & 22 & 37 & 22 \\ \text { Oxygen saturation } & 93 & 87 & 92\end{array}$

Dissolved Oxygen. The oxygen content was determined by Winkler's titration method, and the values for percentage oxygen saturation calculated from Fox's (I907) tables. The precaution advised by Alsterburg (1926) of not permitting the sample, after adding the Winkler's reagents, to stand for more than I5 min. before acidifying, was adopted. This precaution minimizes possible errors due to organic matter and ferric ions.

The determined range for high water was from 5.26 c.c. per 1 . on August 25 to $7 \cdot 78$ c.c. on February 4 . The percentage saturation range was from $79 \%$ on November 20 to I00 \% on February 4 and April 25. This value of $79 \%$ must be regarded as exceptional, since the oxygen saturation value was over $90 \%$ in 35 out of 38 samples taken at high water. This implies that the oxygen saturation is more a function of temperature and salinity than of any other factors. In Fig. 2 the changes in percentage oxygen saturation are shown, and, though by no means well marked, there is an apparent inverse correlation with the height of tide.

Table III shows that on July 27 the oxygen saturation was less at low water than at high water, and other samples taken at low water have a lower oxygen saturation than is general for high-water samples.

Opacity. The amount of suspended matter was considerable. A Secchi's disk of 9 in. diameter became invisible at depths of little more than $0.5 \mathrm{~m}$. at high water. This is approximately the same as in the Tees estuary (Alexander et al. 1935) at the same salinity. However, the value of $0.5 \mathrm{~m}$. is a generous one, since the readings were made at slack water on calm days. As a result of the gradual deposition of silt under such conditions the water becomes clearer. With the beginning of the tidal stream the silt is again stirred up, and a swell, even at slack water, prevents deposition.

The water is more opaque at low water than at high water and, as on July 27 , a pronounced change in opacity may occur about mid-water flood. 
Note must be made of the substantial quantities of coal dust present, as indicated in the tow-nettings. Usually its presence was more clearly marked in the deep hauls, but it was occasionally found in the surface hauls. This depended on the state of the water.

\section{THE BACTERIA}

From February to August 1937 nine samples of sea water were taken at the station, and the bacteria investigated to a limited extent. All the samples were taken at high water. The procedure adopted was, as nearly as possible under the conditions of working, that recommended by the Ministry of Health (1936).

The examinations made were:

(a) Agar count at $20^{\circ} \mathrm{C}$. (room temperature), Table IV.

(b) Agar count at $37^{\circ} \mathrm{C}$.

(c) Coli-aerogenes count.

\section{Table IV Colonies Developing at Room Temperature}

\begin{tabular}{|c|c|c|c|c|c|c|}
\hline Date & 0.5 c.c. & 0.5 c.c. & O.I c.c. & O.I c.c. & Total & $\begin{array}{l}\text { Average } \\
\text { per c.c. }\end{array}$ \\
\hline Feb. I5 & 209 & 183 & .. & .. & 392 & 392 \\
\hline Mar. 6 & 238 & 208 & 45 & .. & $49 \mathrm{I}$ & 446 \\
\hline April II & 340 & 290 & & & 630 & 630 \\
\hline May I3 & $32 \mathrm{I}$ & .. & 60 & 69 & 450 & 643 \\
\hline June 3 & 95 & . & 27 & 18 & I40 & 200 \\
\hline July 7 & 168 & I75 & 56 & 52 & $45 \mathrm{I}$ & 376 \\
\hline July ig & II5 & II 2 & 15 & I3 & 255 & 213 \\
\hline \multirow[t]{2}{*}{ Aug. 25} & I29 & .. & 27 & 33 & 189 & 270 \\
\hline & \multicolumn{4}{|c|}{ Total number of colonies counted } & 2998 & \\
\hline
\end{tabular}

Owing to the spreading over of the plates by sporing organisms, the counts of colonies developing at $37^{\circ} \mathrm{C}$. (Table V) are generally minimum. A number of the incubated plates were rendered useless and were discarded. As, frequently, the whole batch of plates was affected, counts were made of the better plates as long after $24 \mathrm{hr}$. and as near to $48 \mathrm{hr}$. as possible. The counts on July 7 and August 25 were of good plates incubated for the full $48 \mathrm{hr}$., and it is seen that these give quite the highest numbers of the series.

Table V. Colonies Developing at $37^{\circ} \mathrm{C}$.

\begin{tabular}{|c|c|c|c|c|c|c|}
\hline \multirow[b]{2}{*}{ Date } & \multirow[b]{2}{*}{ I c.c. } & \multirow[b]{2}{*}{ I c.c. } & \multirow[b]{2}{*}{0.5 c.c. } & & \multirow{2}{*}{$\begin{array}{l}\text { Average } \\
\text { per c.c. }\end{array}$} \\
\hline & & & & 0.5 c.c. & Total & \\
\hline Feb. I5 & 24 & & I5 & .. & 39 & 26 \\
\hline Mar. 6 & 84 & 69 & & .. & I53 & 76 \\
\hline Mar. Io & 58 & 53 & 33 & $\ldots$ & I 44 & 58 \\
\hline April II & .. & .. & 29 & 23 & 52 & 52 \\
\hline May I3 & .. & .. & & 32 & 32 & 64 \\
\hline June 3 & .. & .. & 18 & 16 & 34 & 34 \\
\hline July 7 & .. & .. & 94 & .. & 94 & 188 \\
\hline July 19 & .. & .. & 47 & 50 & 97 & 97 \\
\hline \multirow[t]{3}{*}{ Aug. 25} & .. & .. & 67 & 76 & I 43 & I 43 \\
\hline & \multirow{2}{*}{\multicolumn{3}{|c|}{$\begin{array}{l}\text { Total number of colonies counted } \\
\text { Average per c.c. }\end{array}$}} & & 788 & \\
\hline & & & & & & 72 \\
\hline
\end{tabular}


The coli-aerogenes counts (Table VI) were obtained by inoculating the sea water and dilutions of it, made by adding the sample to sterilized tap water, into tubes of MacConkey broth. The tubes were incubated for I or 2 days, and, from the number of tubes giving a positive reaction for acid and gas, the probable number of coli-aerogenes colonies in the initial sample was obtained by reference to McGrady's tables (see Ministry of Health, I936). The numbers obtained were so high that it was considered unnecessary to distinguish between Bact. coli and Bact. aerogenes, especially as there are several intermediate types.

\section{Table VI. Colonies Developing in MacConkey Broth}

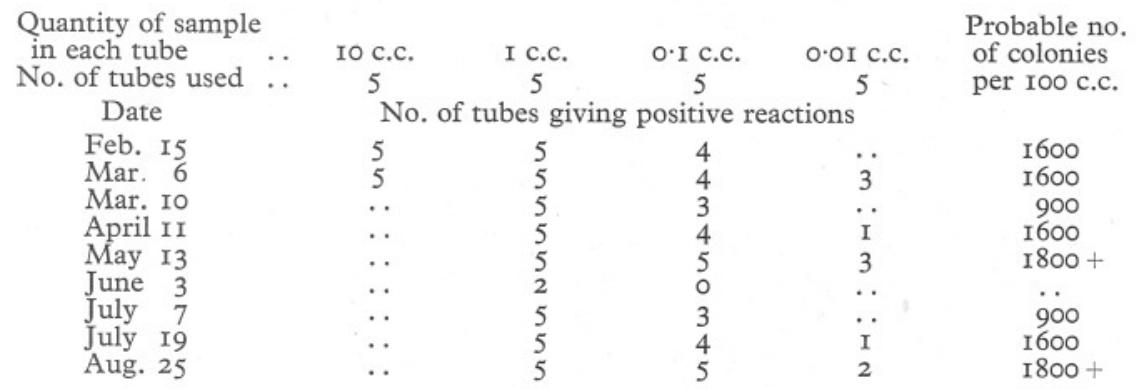

The counts given in Tables V and VI, particularly in the latter, indicate a measure of sewage pollution.

Comparative results are given by Meek $(1923 b)$ for the Tyne estuary. On agar incubated at $37^{\circ} \mathrm{C}$. I000 colonies per c.c. were recorded for March, increasing to 2400 in May. Bact. coli remained constant at about Ioo per c.c. throughout. These numbers are very much higher than those for the plankton station. Lloyd (1930), on the other hand, found lower numbers of colonies developing at room temperature in the surface water in the Clyde Sea area, even in the heavily polluted Greenock and Cumbrae Deep areas. However, in making strict comparison between the three sets of results, the influence of differences of technique on the numbers obtained has to be kept in mind. In this connexion the recent work of Dianova \& Voroshilova (I935) on the salt composition of the medium and the specificity of marine bacteria is important.

\section{The Plankton}

All the tow-nettings were made with a conical tow-net with a mouth $0.5 \mathrm{~m}$. in diameter and silk of 100 meshes to the inch. The net was towed horizontally for $20 \mathrm{~min}$. at the surface, and at times for Io min. at a depth of 2-4 m. from the bottom. Particular attention was paid to the surface hauls which were fully analysed quantitatively, but, owing to the greater amount of detritus, the deep hauls could not be treated in such detail. The method of counting was rigorously standardized from the beginning, counts being made in a 
subsample on a ruled slide. The subsample consisted of 0.5 c.c. and was removed while the plankton sample was being shaken. At least two counts were made. If the difference in the two counts was more than $10 \%$ further counts were made until two counts gave such consistency; usually, however, two counts were sufficient.

Table VII gives the distribution of the tow-nettings for each month. A few of these were taken at night, but, as there was no perceptible difference between night and day hauls, they are not specifically noted.

\section{Table VII. Distribution of Tow-nettings in Each Month}

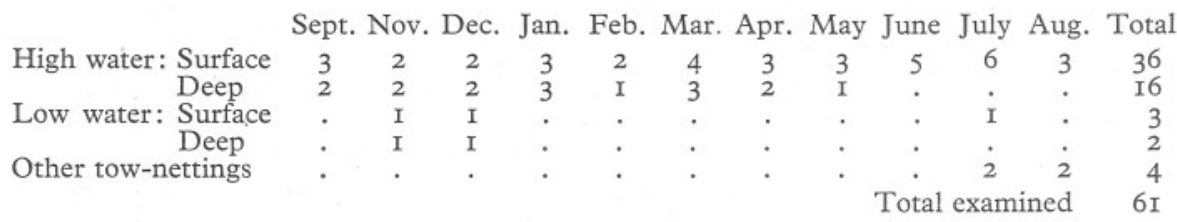

Table XII gives a list of the species identified and the average numbers in the high-water surface counts for each month, except when otherwise noted. This list is not complete, some species present in very small numbers being omitted. Only numbers of 1000 or more for diatoms, and 500 or more for copepods and larval forms, are considered significant, and other numbers are not shown except when the maximum number obtained is given as an indication of frequency and seasonal distribution.

\section{Diatoms}

Twenty-four species of diatoms (Table XII) have been identified and all these, except the estuarine species Nitzschia sigma W.Sm., ${ }^{\star}$ are typically marine. The bulk of the diatoms collected consisted of Biddulphia sinensis Grev., Rhizosolenia setigera Brightw., Biddulphia regia M. Schultze and Bacillaria paradoxa Gmel. Next in importance came Streptotheca thamensis Shrubs., but even though increasing to the end of the period, it was throughout overshadowed by the numbers of the four main diatoms. Centrifuged samples indicated that Skeletonema costatum (Greville) and small Coscinodiscus species were the most frequent diatoms in the summer and not the diatoms caught by the tow-net. This is to be expected from the collecting method used, and it is to be understood that the present account of the diatoms in this area is virtually reduced to a consideration of four species only.

The average total diatom counts for each month are given in Table VIII and Fig. 3. From these it is apparent that the maximum number occurred in November, and the minimum in April. These numbers are, however, not particularly instructive. From the middle of November onwards Biddulphia sinensis gradually decreased in numbers and yet it made up more than $50 \%$

\footnotetext{
* I am indebted to Dr M. V. Lebour for confirming this identification.
} 
of the samples until the beginning of May. This decline, therefore, obscures the changes in numbers of the other diatoms. Table VIII and Fig. 4 give the average numbers of all diatoms counted, with the exception of $B$. sinensis. These showed a minimum in December with a steady rise to the highest number in August. The steadiness of this rise is noteworthy. Except between January and February the diatom numbers are not doubled from one month to the next.

By comparing the two numbers for each month in Table VIII it can also be seen that the samples in August 1937 were very different in composition from those in September and especially November 1936. The tow-netting

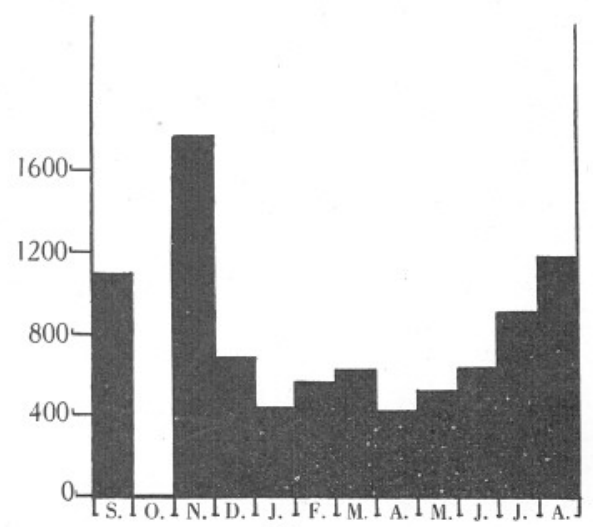

Fig. 3 .

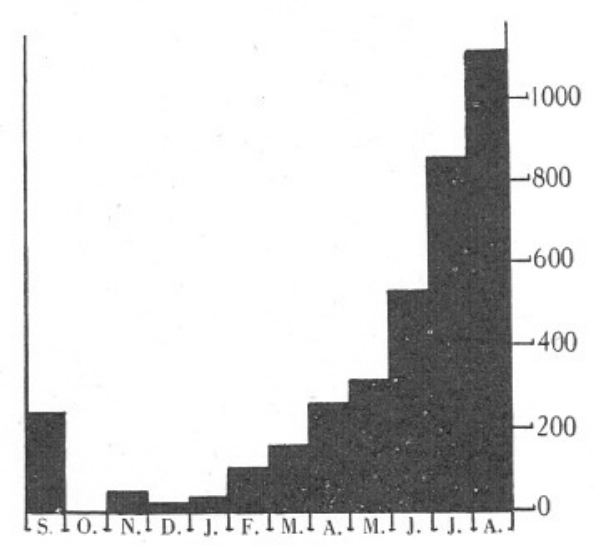

Fig. 4.

Fig. 3. The average numbers per month of all the diatoms counted in the tow-nettings. (No observations in October.)

Fig. 4. The average numbers for each month of all the diatoms except Biddulphia sinensis in the tow-nettings. (No observations in October.)

taken at the end of September I937 still showed this difference. In the beginning of the period $B$. sinensis made up practically the whole of the samples, while at the end of the period it was relatively unimportant. The proportion B. sinensis to other diatoms changed from $7: 2$ in September and 34: I in November to I : 26 in August.

\section{Table ViII. Average Number of Thousands of Diatoms Per Month}

$\begin{array}{lrrrrrrrrrrr} & \text { Sept. } & \text { Nov. } & \text { Dec. } & \text { Jan. } & \text { Feb. } & \text { Mar. } & \text { Apr. } & \text { May } & \text { June } & \text { July } & \text { Aug. } \\ \begin{array}{l}\text { Total diatoms } \\ \text { Total less Bid- }\end{array} & \text { I080 } & \text { I750 } & 672 & 432 & 567 & 620 & 420 & 518 & 625 & 900 & \text { II70 } \\ \begin{array}{l}\text { dulphia sinensis } \\ \text { dul }\end{array} & & 50 & 22 & 32 & 107 & 160 & 260 & 318 & 533 & 860 & \text { II27 }\end{array}$

In Fig. 5 the changes in the values for each of the four main diatoms, expressed as percentages of the total diatoms counted, are related to the height of the tide. A series of values of under 10 $\%$ for any diatom is considered insignificant. 
On the basis of the information in this figure, the period of survey can conveniently be divided into four periods.

September 19-February 4. During this period B. sinensis made up more than $90 \%$ of the diatom samples. This made the changes in percentage of all other diatoms insignificant and, in addition, made the changes in $B$. sinensis itself insignificant so that this period is not included in Fig. 5.

February 4-April I7. This period is shown ir. Fig. 5. On February 4 the percentage value of B. sinensis was $97 \%$ and of Bacillaria paradoxa $\mathrm{I} \%$. On

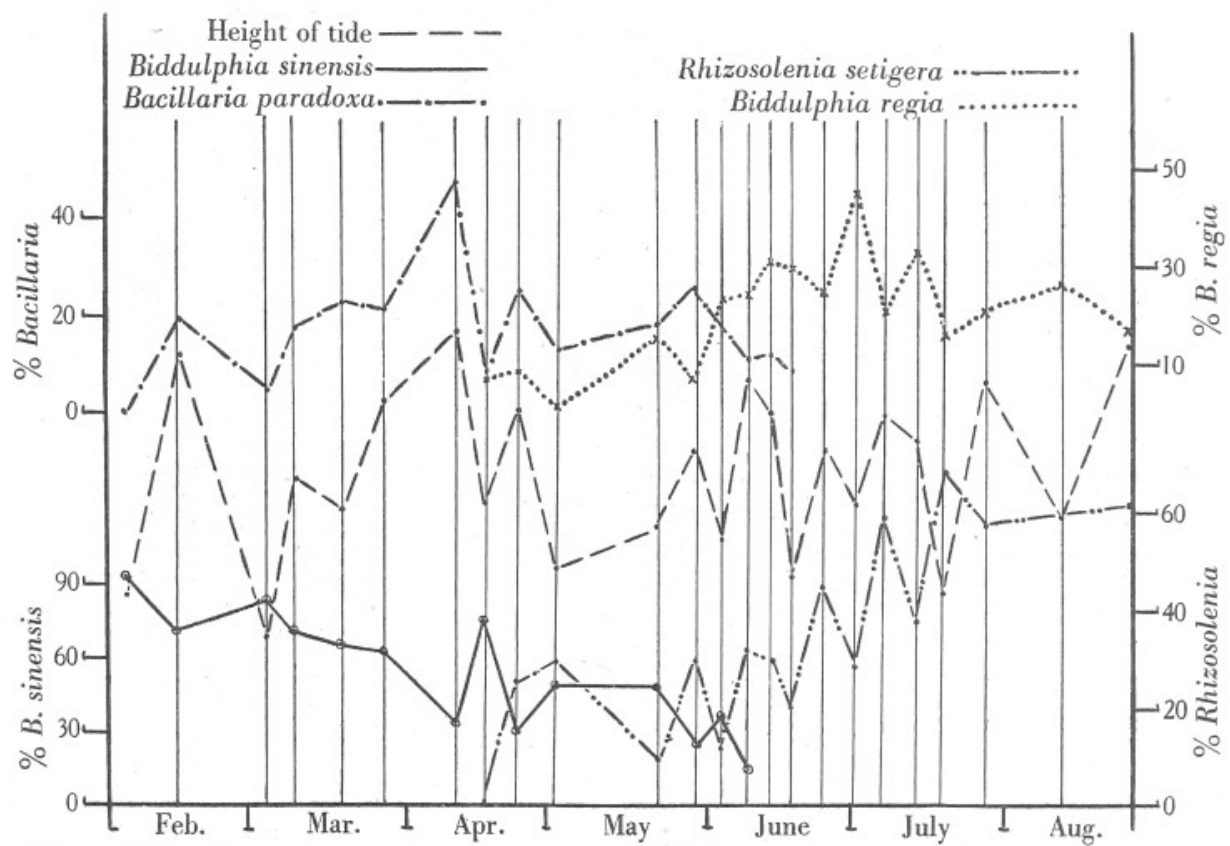

Fig. 5. The relations between the height of tide and the percentage of the four main diatoms to the total diatoms counted in the samples from February 4 to August 25 .

February 15 there was a change to $74 \%$ and $20 \%$. This is the first stage of a period in which the values of Biddulphia sinensis varied inversely, and those of Bacillaria varied directly, with the height of the tide.

April I7-June I8. During this period a transition occurred between the conditions in the last period and the next. Biddulphia sinensis and Bacillaria were still correlated with the height of the tide, but approached the value of $10 \%$ and by June 18 became insignificant. Rhizosolenia setigera suddenly jumped from under I $\%$ on April I 7 to $25 \%$ on April 25 . Up to May 2I the values had no distinct relation with the height of the tide, but from that date they were directly correlated. Biddulphia regia was insignificant until May 2I (although Fig. 5 includes values from April 25) and from then on was inversely correlated with the height of the tide. 
June I8-August 25. During this period only two diatoms were concerned. The percentage values of Biddulphia regia continued their inverse relation, and those of Rhizosolenia setigera their direct relation with the height of the tide. These correlations are well marked and do not break down until July I9. From then onwards the correlations are indefinite, the values differing little from time to time.

Within the actual total numbers of diatoms there are (Fig. 5) diatoms showing different relations with the height of the tide. Although effective in

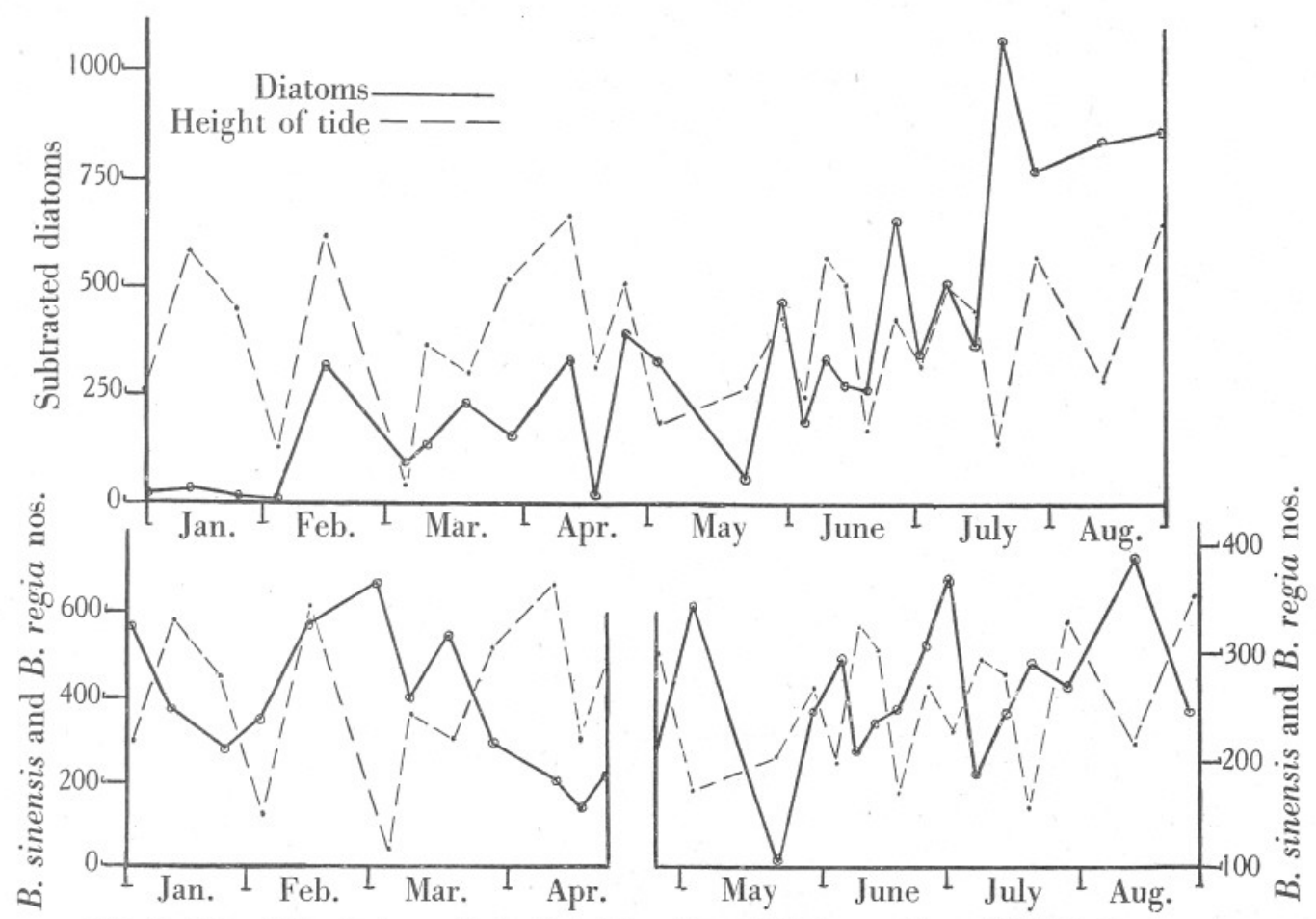

Fig. 6. The relation between the height of the tide and (I) the numbers of Biddulphia sinensis plus B. regia, (2) the numbers of the remaining diatoms, in the samples from January 5 to August 25.

different periods Biddulphia sinensis and B. regia agree in being inversely correlated, and Rhizosolenia and Bacillaria agree in being directly correlated with the height of the tide. In Fig. 6 this distinction is recognized. Here are given the changes in the actual numbers obtained of Biddulphia sinensis plus $B$. regia, and the changes in the numbers of the remaining diatoms. In the first of these there is a clear inverse relation with the height of the tide and in the latter a direct relation. The correlations are by no means exact, but since we are dealing with numbers in which enormous variation may occur, owing to the quantitative method used, such a result is to be expected. 
There is no persistent correlation between the height of the tide and the total number of diatoms, and these correlations become apparent only when a distinction is made between the diatoms according to the information in Fig. 5.

On July 27 five tow-nettings were taken from one high water to the next. Table IX gives the percentage composition of the diatoms in each townetting. These values are plotted in Fig. 7 and show that the composition varied considerably between high water and low water. At high water Rhizosolenia was dominant and at low water Biddulphia regia made up the bulk of the catch. The values for Bacillaria and Biddulphia sinensis indicate also, in so far as one can accept changes within this range of values, that

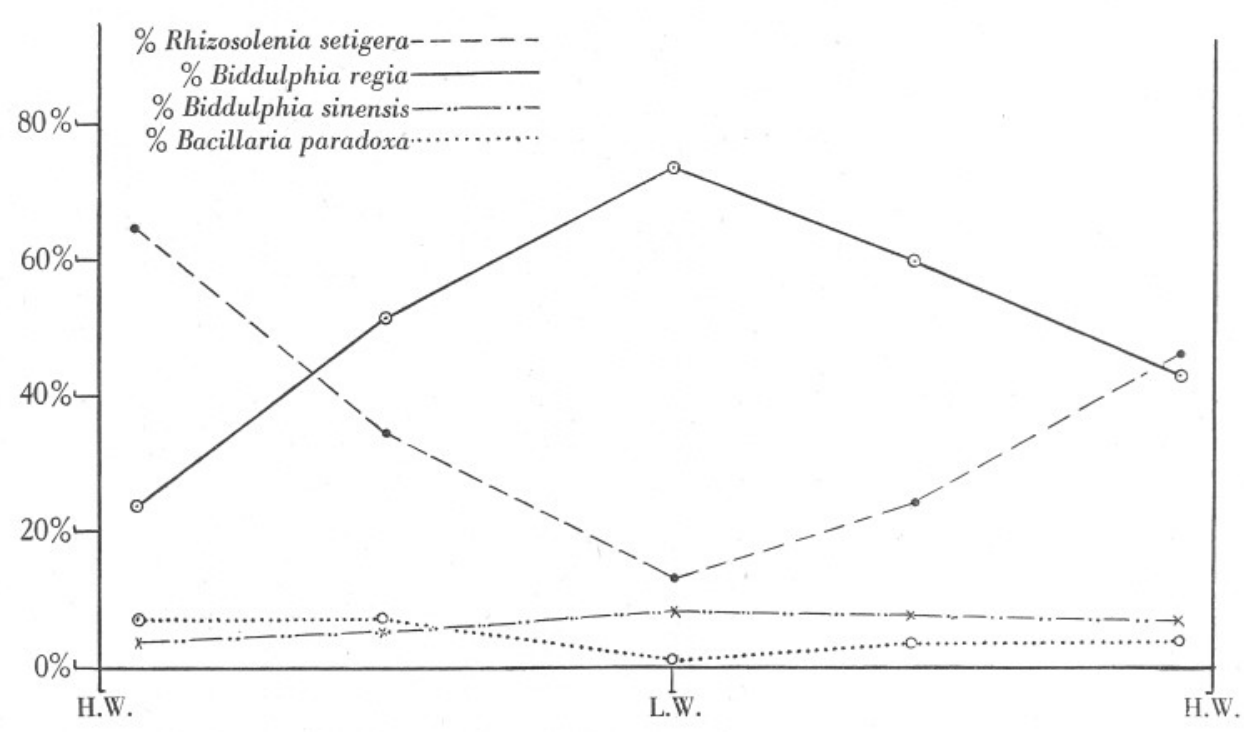

Fig. 7. The changes in the percentage composition of the diatom samples with state of tide on July 27 .

Bacillaria decreased and Biddulphia sinensis increased in percentage values at low tide. Care is required in considering these, since the values at high water were conditioned by Rhizosolenia and at low water by Biddulphia regia.

Table IX. Percentage Composition of Diatoms on July 27

$\begin{array}{lcccc} & \text { Rhizosolenia } & \begin{array}{c}\text { Biddulphia } \\ \text { regia }\end{array} & \text { Bacillaria } & \begin{array}{c}\text { Biddulphia } \\ \text { sinensis }\end{array} \\ \text { High water } & 65 & 24 & 7 & 4 \\ \text { Mid-water ebb } & 35 & 52 & 8 & 6 \\ \text { Low water } & 14 & 74 & 2 & 9 \\ \text { Mid-water flood } & 25 & 6 \mathrm{I} & 5 & 9 \\ \text { High water } & 46 & 43 & 5 & 6\end{array}$

The diatom numbers in each haul are relative only to one another. In order to obtain numbers which could be compared with those from other areas, 
water samples of 20 c.c. were centrifuged at intervals from the end of April to July and the diatom chains counted. Owing to the considerable quantities of silt there was a limit to the volume of water that could be centrifuged, and, even so, the counts obtained are minimum owing to the masking effect of the deposited silt. The counts were so low, however, that errors are unimportant. The counts varied from 72 diatom chains per 20 c.c. on June 3 to 22 on May I3. Fig. 8 shows an inverse relation between the numbers and the height of the tide. Samples in November gave counts of under Io diatom chains per 20 c.c. and sometimes there were no diatoms present.

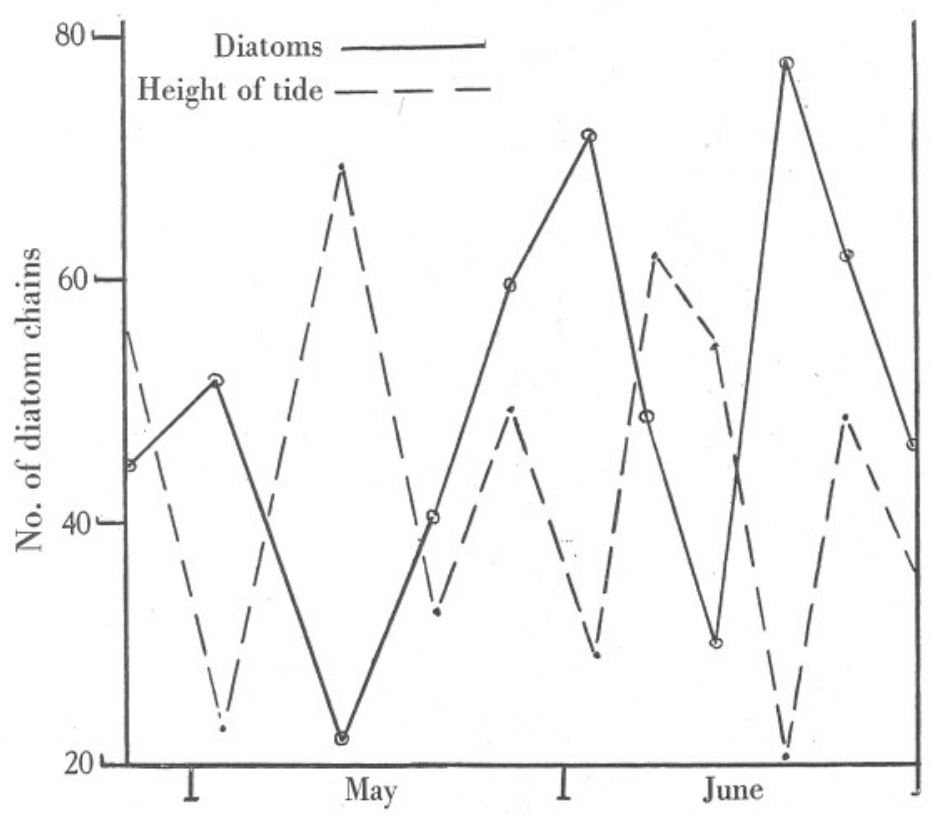

Fig. 8. The relation between the height of tide and the number of diatom chains in 20 c.c. of water from April 25 to July I.

\section{Copepods}

Only eight species of pelagic copepods (Table XII) are recorded from the station, and, of these, five species alone were present in significant numbers. These were, in order of importance, Eurytemora affinis (Poppe), Acartia bifilosa (Giesbrecht), Euterpina acutifrons (Dana), and, of much lesser significance, Oithona nana Giesbrecht and Centropages hamatus (Lilljeborg). The other species were present sporadically and in small numbers. Fig. 9 presents the seasonal distribution in the numbers of the three main species.

Eurytemora affinis was the most interesting copepod obtained. Variations in numbers from time to time were sufficiently great to represent changes in actual density at the station, rather than changes due to unequal or 
inefficient sampling by the tow-net. I have followed Gurney (I93I) in not separating the form $E$. hirundoides from $E$. affinis. As yet the copepodid stages and adults have not been analysed, and the numbers refer to the total Eurytemora irrespective of stage.

While a varying number of specimens were obtained outside this period, Eurytemora reached significant numbers, i.e. 500 or over, between November 3 and June 8. The highest average for any month occurred in April (Fig. 9)

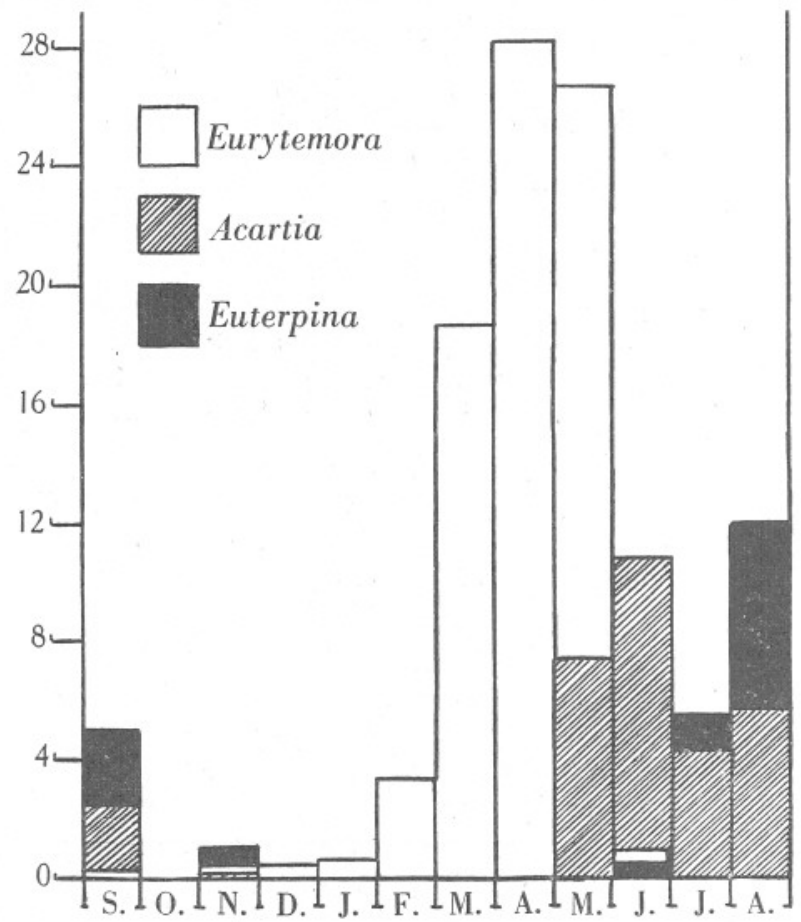

Fig. 9. The average numbers per month of the three chief copepods. (No observations in October.)

with over 28,000 , and this was closely followed in May with nearly 27,000 . The highest number obtained at the surface was 59,000 on May 2I, and it is this number which makes the average for May high, since on May 27 a sudden decrease in numbers was obtained (Table X). A further decrease occurred on June 8. The rapidity of this decrease is striking.

Table X. Numbers of EURYTEMORA AND ACARTIA

\begin{tabular}{|c|c|c|c|c|c|c|}
\hline Date & Apr. 25 & May 3 & May 2 I & May 27 & June 3 & June 8 \\
\hline $\begin{array}{l}\text { Eurytemora } \\
\text { Acartia } \\
\text { Height of tide }\end{array}$ & $\begin{array}{c}32,000 \\
37 \mathrm{ft} .4 \text { in. }\end{array}$ & $\begin{array}{c}17,000 \\
800 \\
30 \mathrm{ft} .6 \mathrm{in} .\end{array}$ & $\begin{array}{c}59,000 \\
20,000 \\
32 \mathrm{ft} .4 \mathrm{in} .\end{array}$ & $\begin{array}{c}3,200 \\
\text { I, 600 } \\
35 \mathrm{ft} . \mathrm{I} \text { in. }\end{array}$ & $\begin{array}{c}4,800 \\
25,600 \\
31 \mathrm{ft} .8 \mathrm{in} .\end{array}$ & $\begin{array}{r}400 \\
13,200 \\
38 \mathrm{ft} .5 \mathrm{in}\end{array}$ \\
\hline
\end{tabular}


In Fig. Io the numbers of Eurytemora obtained at the surface are plotted against the height of the tide. Allowing for the sudden drop in numbers on May 27, there appears to be a direct correlation, with a single exception in the coincidence of the form of the curves on April I7. In this figure, also, is plotted the numbers of diatoms caught in the period, and there is, here, an inverse relation between surface Eurytemora and diatoms. This is to be expected, since, during this period, Biddulphia sinensis made up more than $50 \%$ of the diatoms collected and the diatom curve will tend to follow the $B$. sinensis curve, i.e. inverse with the height of the tide.

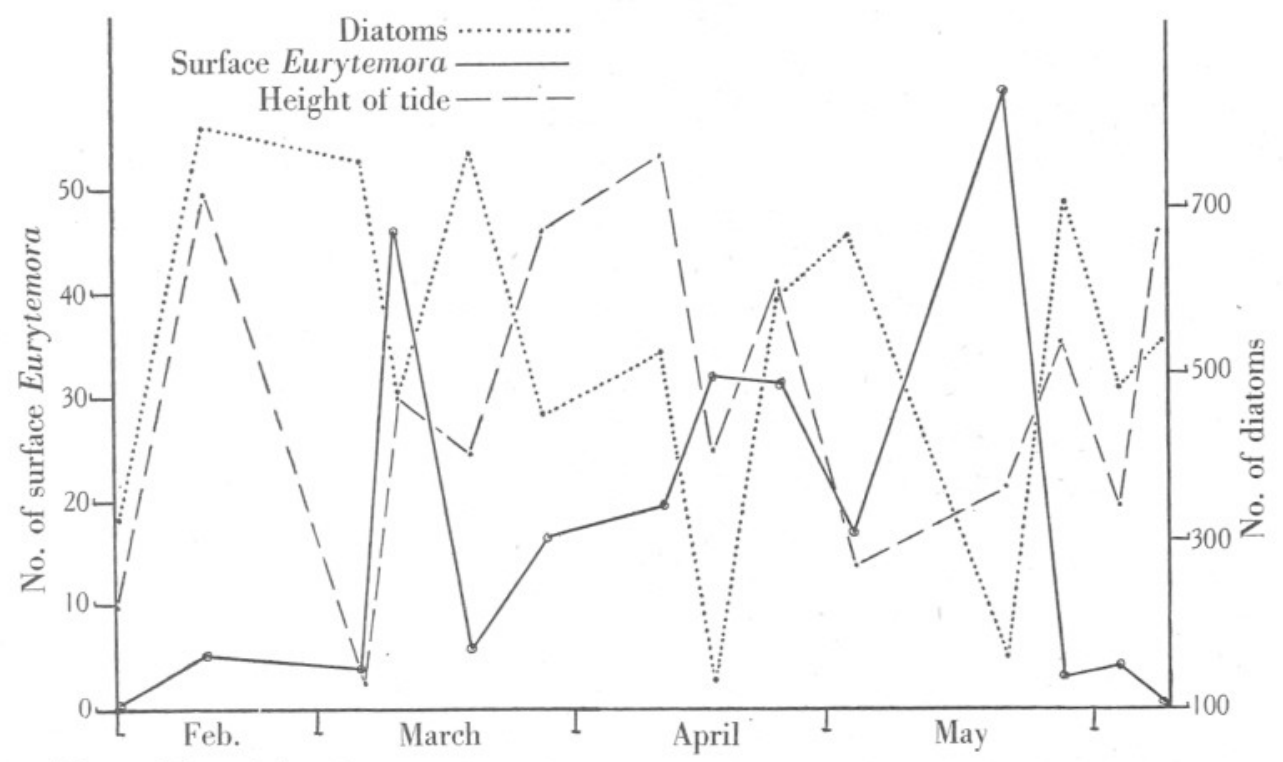

Fig. Io. The relations between the surface Eurytemora and (I) height of tide, (2) total diatoms, from February 4 to June 8 .

Over a short period quantitative data for Eurytemora are available from deep hauls. The numbers obtained were higher than at the surface. On March 6, for example, over a quarter of a million were obtained in 10 min. towing. Since the duration of the bottom hauls was half that of the surface hauls the numbers are here doubled. The total numbers of Eurytemora obtained from the surface and the bottom, when both records are available, are plotted in Fig. II. In contrast to Fig. Io there is an inverse correlation with the height of the tide. The surface Eurytemora, expressed as percentages of the total Eurytemora obtained, are also plotted in this figure, and their direct correlation with the height of the tide is well marked.

Acartia bifilosa. This species was present in significant numbers up to November 20 and from May 3 to the end of the survey. Table X shows that, at about the time of the rapid decline in numbers of Eurytemora, there was 
a rapid increase in the numbers of Acartia, and also that, during this period, the numbers were inversely correlated with the height of the tide. On no occasion after June 8 were more than I0,000 Acartia obtained, so that variation in numbers may well have been due to unequal sampling.

Euterpina acutifrons agreed closely with Acartia in time distribution, and was significantly present up to November 27 and from May 27 to the end of the survey. In this species, the rise in numbers to the maximum of 20,000 on August 25 was gradual.

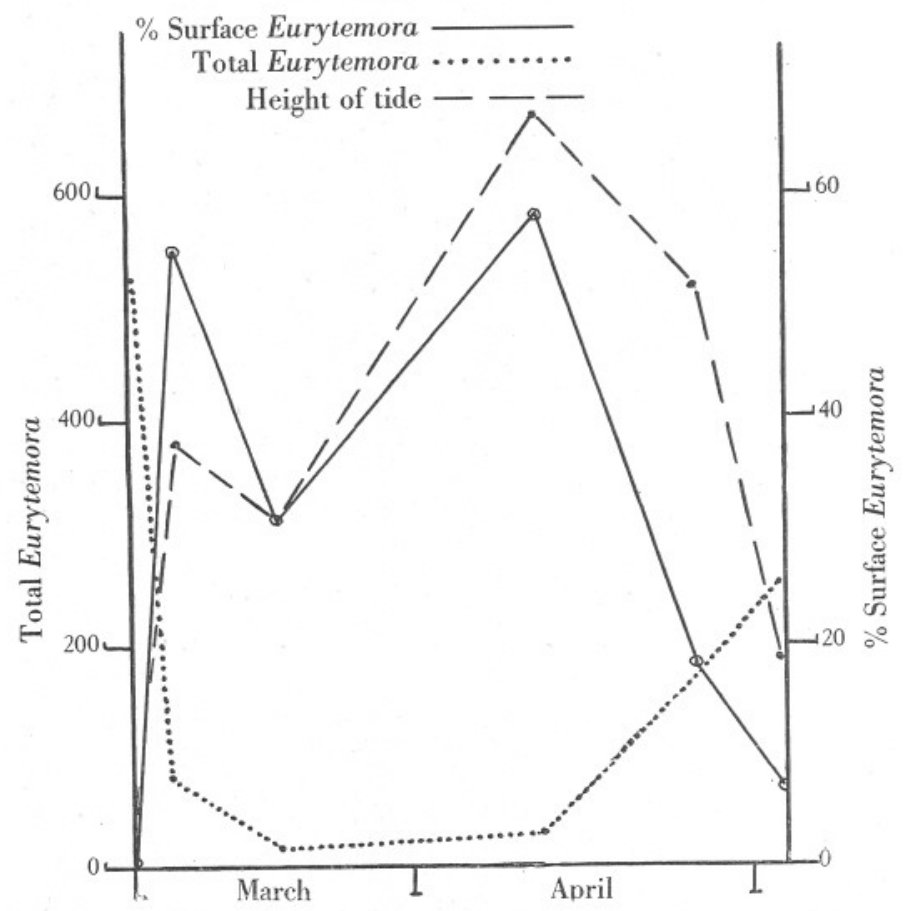

Fig. II. The relations between the height of tide and (I) total Eurytemora, (2) percentage of the total Eurytemora at the surface.

Oithona nana was present in significant numbers from September 6 to December 2I. Except for a few specimens at the end of the period of survey it did not reappear.

Centropages hamatus was present in significant numbers only in September, though a few specimens were present at the end of the survey.

Table XI gives the percentage distribution of the copepods with the state of the tide on two separate occasions. We see here that Eurytemora was quite unimportant at high water, but was the dominant form at low water. Euterpina was the most frequent copepod at high water, while Acartia appears to maintain an even percentage value, but it must be realized that its value at 
high tide is determined by Euterpina and at low water by Eurytemora. Oithona was present at one high tide only.

\section{Table Xi. Percentage Distribution of Copepods with State of Tide}

$\begin{array}{cccccc}\text { Date } & \text { State of tide } & \text { Acartia } & \text { Eurytemora } & \text { Euterpina } & \text { Oithona } \\ \text { July 27 I937 } & \text { High water } & 4 \mathrm{I} & 4 & 55 & . \\ \text { Sept. 20 I937 } & \text { Low water } & 40 & 58 & 2 & . \\ & \text { High water } & 22 & 58 & 20 & . \\ & \text { High water } & 24 & . & 67 & 9\end{array}$

The list of harpacticids (Table XII) is not unusual for estuaries or turbulent water. Tisbe furcata (Baird) was interesting in that a number of the specimens carried the suctorian Ophryodendron trinacrium Grüber.

\section{Other Organisms}

The remaining species and larval forms identified are of little interest. As with the diatoms and the copepods, there is a distinct poverty in the number of species. A considerable number of the species listed in Table XII cannot be considered pelagic, and are present in the tow-nettings, as commonly in other estuaries, owing to the turbulence of the water.

As regards the larger Crustacea, the numbers give little indication of their frequency since the tow-net used was too fine to catch good samples of, for example, the mysids. The largest number of mysids taken was 75 at the surface at low water. Usually there were more mysids and amphipods in the deep hauls, but there was no marked difference between day and night hauls.

Of the larval forms, cirripede nauplii were present in greatest numbers, with a maximum in April. The numbers for the polychaete larvae are shown as those of Nerine, Autolytus and general polychaete larvae. This latter group, during the summer and autumn, consisted mainly of the larvae of Sabellaria alveolata Linn. (Wilson, 1929) which is common along the shore and is probably present on the bottom under the plankton station.

Both Podon polyphemoides and ascidian tadpoles appeared suddenly on June 18 and had virtually disappeared by June 24 .

\section{Discussion}

It has already been explained (p. 398) that, because of the varying speeds of the tidal stream, the observations made at the station are referable to a series of points along a length of the channel, and that the points can be related to one another by the height of the tide, i.e. the highest spring tide refers to the farthest point concerned down-channel and the lowest neap tide to the nearest point down-channel, and so on. Therefore the vertical measure of the height of the tide can be used as a horizontal measure of a length of channel. This length will be referred to as the investigated length. 
Table XiI. List of Species and Average Monthly Catches

Diatoms. Nos, refer to thousands cMelosira Borreri Greville cParalia sulcata (Ehr.)

Coscinodiscus Grani Gough Coscinodiscus excentricus $\mathrm{Ehr}$ Coscinodiscus radiatus Ehr. Actinoptychus undulatus (Bail.) Actinoptychus undulatus (Bail.) Actinoptychus splendens (Ehr.) Rhizosolenia setigera Brightw. cChaetoceros borealis Bailey

cChaetoceros didymis Ehr. Biddulphia regia M. Schultze Biddulphia sinensis Grev. Biddulphia favus (Ehr.) cBellarochia malleus (Brightw, cBellarochia malleus (Brightw.) Dytilium Brightwelli (West)
cStreptotheca thamensis Shrubs. cAsterionella japonica Cleve \& Möller cAsterionella kariana Grun cThalassiothrix nitzschioides Grun Gyrosigma sp. Hassal cBacillaria paradoxa Gmel.

Nitzschia sigma W. $\mathrm{Sm}$.

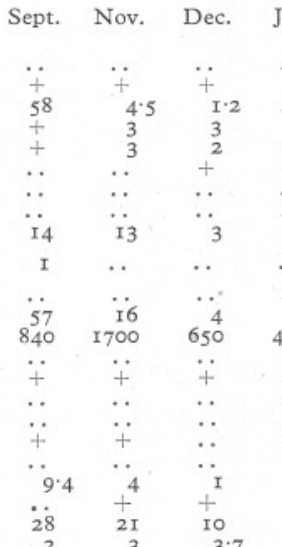

Other phytoplankton organisms. Nos. refer to thousands Ceratium furca (Ehrenberg) Halosphaera viridis $\mathrm{Schmitz}$

Copepods. Nos. refer to hundreds Calanus finmarchicus (Gunnerus) Pseudocalanus elongatus Boeck Centropages hamatus (Lillejeborg) Temora longicornis (O. F. Müller) Eurytemora affinis (Poppe) Acartia bifilosa (Giesbrecht) Euterpina acutifrons (Dana) Euterpina acutifrons (Dan

Podon polyphemoides Leuck. Peracarids

Gastrosaccus spinifer (Göes) Schistomysis spiritus (Norman) Schistomysis ornata (G. O. Sars) Mesopodopsis slabberi (van Ben.)

Neomysis integer (Leach) Neomysis integer (Leach)
Diastylis rathkei (Kröyer) Diastylis rathkei (Kröye
Eurydice pulchra Leach

Sphaeroma serratum (Fabr.)

Notropis swammerdami (H. MilneEdwards) Gammarus locusta (L.) Gammarellus homari (Fabr.)

Decapods

Pandalus montagui Leach Crangon vulgaris $\mathrm{L}$. Crangon vulgarls $\mathrm{L}$.

Other zooplankton species

Foraminifera

Pleurobrachia pilosa (O. F. Müller) Sagitta setosa J. Müller Eteone sp.

Oikopleura dioica Fol.

Elvers

Larval forms

Ephyra

Cyphonautes

Echinoplutei
Post larval asteroids

Larvae of Nerine

Autolytus larvae

Polychaete larvae

Nauplii

Cirripede nauplii

Cypris larvae

Cryponiscid

Macruran protozoea

Megalopa

Zoea of Carcinus maenas

Gastropod larvae

Lamellibranch larvae

Ascidian larvae

Ovum hispidum hystrix

Harpacticids

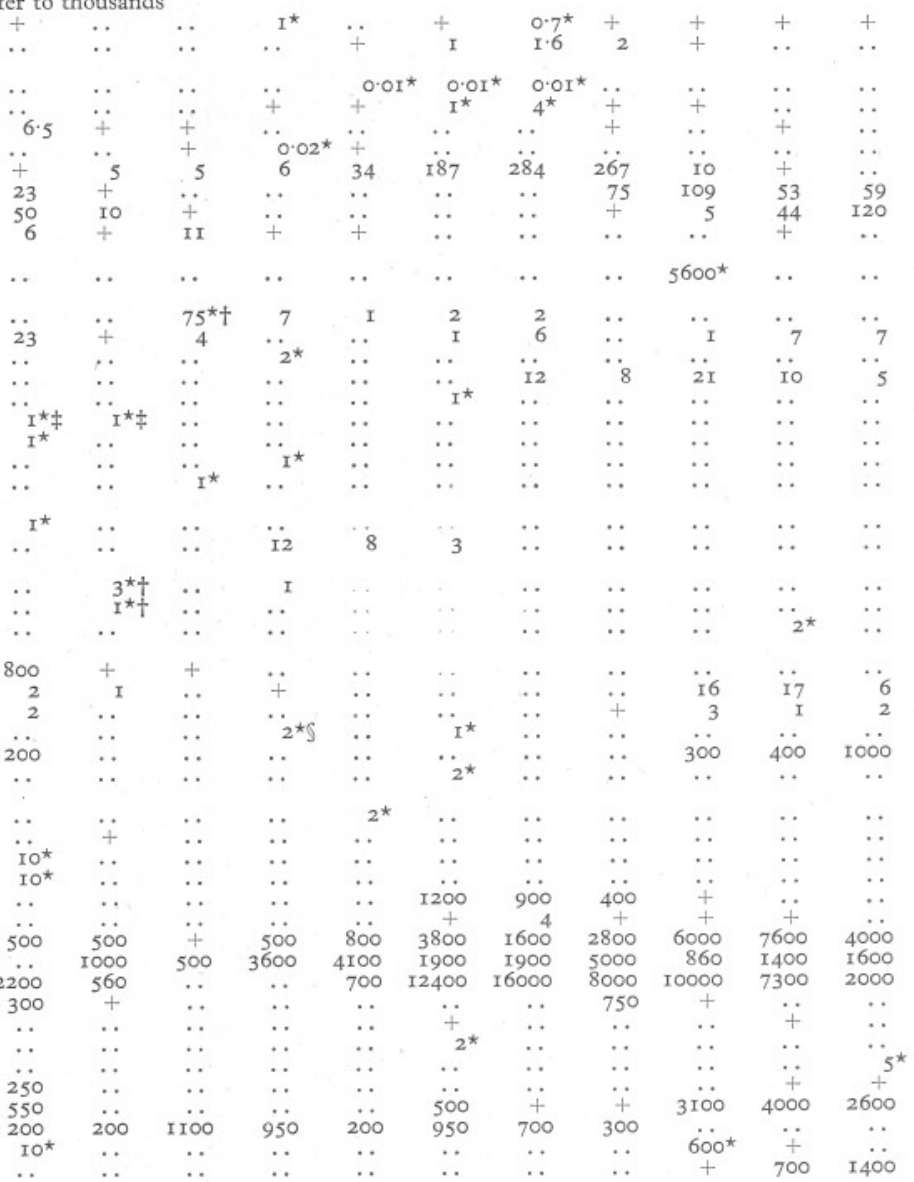

Longipedia minor Scott

Canuella perplexa Scott

Ectinosoma curticorne Boeck

Zaus goodsiri Brady

$$
\begin{aligned}
& \text { Alteutha interrupta (Goodsir) } \\
& \text { Tisbe furcata (Baird) } \\
& \text { Tachidius littoralis Poppe } \\
& \text { Tachidius discipes. Giesbrecht } \\
& \text { Macrocheiron fucicolum Brady }
\end{aligned}
$$

* Number in a single tow-netting only.

$\$$ Night tow-netting.

$\dagger$ Low-water haul.

$\mp$ Bottom haul. $c$ Numbers refer to chains of diatoms. 
Since the higher the tide the farther down-channel is the point involved in investigation, the direct correlation between the salinity and height of tide (Fig. 2) means that there was a gradient of increasing salinity from up-channel to down-channel. Quite apart from this correlation, such a gradient is to be expected, and the existence of the correlation serves as a check on the distinction between observations at a single point and along a length of channel. It also shows that changes in values along the investigated length are sufficiently large to be easily observable. While normal variations in rainfall do not upset this correlation, it is possible, as Prof. Tattersall suggests, that the local influx of fresh water from the Taff and adjacent rivers causes a steeper gradient in the region of the station than farther out in the channel. If this is so the range of values at a station nearer mid-channel would not necessarily be greater than at the present station, in spite of the increase of the investigated length due to greater divergence in the speeds of the spring and neap tidal streams.

The inverse relation between the phosphate values and the height of the tide indicates a gradient of decreasing phosphate. This is further borne out in Table III which shows that phosphate values are higher at low water. Low water observations refer, of course, to a point considerably farther upchannel than the investigated length.

Table III shows, also, that the oxygen saturation was less at low water than at high water, yet Fig. 2 appears to indicate, from the inverse correlation with the height of tide, that there was a decreasing oxygen saturation from up-channel to down-channel. These results are not necessarily inconsistent. Meek $(1923 b)$ found that the dissolved oxygen content in the Tyne estuary is almost entirely dependent on fresh water from upstream. The fresh water coming down from the Taff, Ely and Rhymney may be effective in the same way and cause a gradient in oxygen saturation from the point of entry of the fresh water. The water that forms a state of low water at the station is only for a short period under the influence of these rivers, and, with the flood tide, moves up-channel outside their range. In this position it may enter a region where the effect of contaminating products causes a lower saturation.

There are, undoubtedly, gradients of other factors which have not been determined, particularly opacity, and possibly contaminating products as suggested by the higher phosphate and lower oxygen saturation at low water. While it is not possible to define all the gradients individually, the values for the height of the tide summate the effects of the gradients as a whole.

The water within the investigated length cannot be regarded as distinct and isolated. It becomes mixed with, and replaced by, partially or ultimately completely, up- or down-channel water. This process is, in the last place, dependent on the fresh water flowing into the estuary and channel on the up-channel side. When the up-channel water is dominant there is a drop in salinity in the investigated length. With decreasing rainfall the effect of the up-channel water is lessened, and the down-channel water mixes with, and 
replaces, the water in the investigated length, thus increasing the salinity. The measure of the dominance of one or other body of water is given by the average monthly salinities (Table I), and changes in values indicate that up-channel water entered the investigated length from September to February, and that down-channel water entered from February to the end of the period. Apparently this process had an annual cycle. The water that entered the investigated length from up- or down-channel brought in with it its own plankton, which mixed with the plankton already there, and gave to this mixed plankton a new environment. This process is referred to as the annual cyclical movement.

An outflow of less saline water along the surface of the channel, as in the Tees estuary (Alexander et al. I935), appeared to play a negligible part and occurred only under exceptional conditions. This is easily understandable since the bulk of fresh water enters the channel far above the investigated length, and the mixing processes, induced by the tidal streams, would cause any such layer to lose its identity before arriving at the investigated length.

The correlations in Fig. 5 show how the diatoms can be related to one another within the investigated length. The percentages of Biddulphia sinensis and $B$. regia in the samples agree in being inversely correlated, and the percentages of Rhizosolenia setigera and Bacillaria agree in being directly correlated with the height of the tide. Two periods are distinguished. From February to May the correlations determine that Biddulphia sinensis was more up-channel than Bacillaria, and from June to August that Biddulphia regia was more up-channel than Rhizosolenia setigera.

\section{Biddulphia sinensis $\rightarrow$ Bacillaria. Biddulphia regia $\rightarrow$ Rhizosolenia .}

Further, from the correlations in Fig. 6 it is clear that, in their respective periods, Biddulphia sinensis and B. regia were more frequent on the upchannel side, and Rhizosolenia and Bacillaria on the down-channel side.

Of the copepods only Eurytemora varies sufficiently along the investigated length to permit of analysis. Fig. Io indicates, from the direct correlation, that the surface Eurytemora were more frequent down-channel than upchannel. This appears to be quite inconsistent with the known behaviour of Eurytemora in other areas (Percival, 1929). When, however, the total Eurytemora obtained, both from surface hauls and deep hauls, are plotted against the height of the tide (Fig. II) an inverse correlation appears which shows that actually Eurytemora was a more up-channel form. The direct correlation between the height of the tide and the percentage of the total Eurytemora at the surface (Fig. II) shows that the farther down-channel the more evenly were the Eurytemora distributed from the surface to the bottom. On the up-channel side of the investigated length the large majority of the Eurytemora was at the bottom. It is this variation in vertical distribution along 
the investigated length which explains the difference in correlations between the surface Eurytemora, the total Eurytemora, and the height of the tide.

From the plankton results the annual cyclical movement is illustrated best by the copepods. Since the changes in average monthly salinities measure the influx of up- or down-channel water, a comparison of Fig. 9 with the average salinities for the corresponding months (Table I) suggests that the copepod succession from up-channel to down-channel was

$$
\text { Eurytemora } \rightarrow \text { Acartia } \rightarrow \text { Euterpina. }
$$

This evidence is insufficient, since some factor, such as temperature, may determine the succession, but the composition values for July 27 (Table XI) do, however, substantiate the suggestion and allow the addition

\section{Euterpina $\rightarrow$ Oithona.}

Since Centropages hamatus followed Oithona in time, the succession can probably be further extended to

\section{Oithona $\rightarrow$ Centropages.}

It is of interest that, working at one place in the channel, a succession of copepods was obtained which illustrates part of the range from purely brackish water species to purely oceanic species (see Russell, 1936, quoting Ostenfeld, I93I).

Brackish water, e.g. Eurytemora affinis.
Littoral, and brackish water, e.g. Acartia bifilosa.
Neritic, low salinity, e.g. Oithona nana.
Neritic, e.g. Centropages hamatus.

The data which have been presented indicate the importance of space, and an ideal figure representing the changes in the plankton should be three dimensional, with a consideration of the changes in relation to both time and space. Apart from the difficulties of constructing such a figure, the available data are not sufficient for such a construction. In Fig. I2 is shown a strictly diagrammatic attempt, without attention to scale, to give the arrangements of the four main diatoms. $A B$ represents the investigated length of channel concerned from February to the end of April, with $A$ on the up-channel side, and $C D$ represents the length between June I8 and the end of the period, with $C$ on the up-channel side. The sections $A B$ and $C D$ depend on the relations shown in Fig. 5 and Fig. 6.

If the change in the diatoms $A B$ to $C D$ was continuous, then some such arrangement as in $B C$ seems possible. It is to be understood that the sections $A B$ and $C D$ are the assumed arrangements at any point instant of time, and are, therefore, purely spatial arrangements. They are synthesized from a number of observations. The spatial arrangement in the interval between the conditions in $A B$ and $C D$ cannot be determined from available observations, 
and, since the hypothetical arrangement in $B C$ represents a process of change, the time element cannot be neglected. It may be expected that $A D$ represents the length of channel involved in the annual cyclical movement, thus making the arrangement in $B C$ also spatial. If this was so, then it is clear Bacillaria should have been more up-channel than Biddulphia regia.

Against the height of the tide in Fig. I3 are plotted the number of Biddulphia regia to one Bacillaria on each occasion from June 3 to the end of the survey. The inverse relation indicates that the farther up-channel, the more Biddulphia regia were there compared with Bacillaria. Therefore, Biddulphia regia, even in this period, was more up-channel than Bacillaria. This means that the decrease of Bacillaria was not due to a movement up-channel out of the investigated length, but an actual decrease independent of, at least directly,

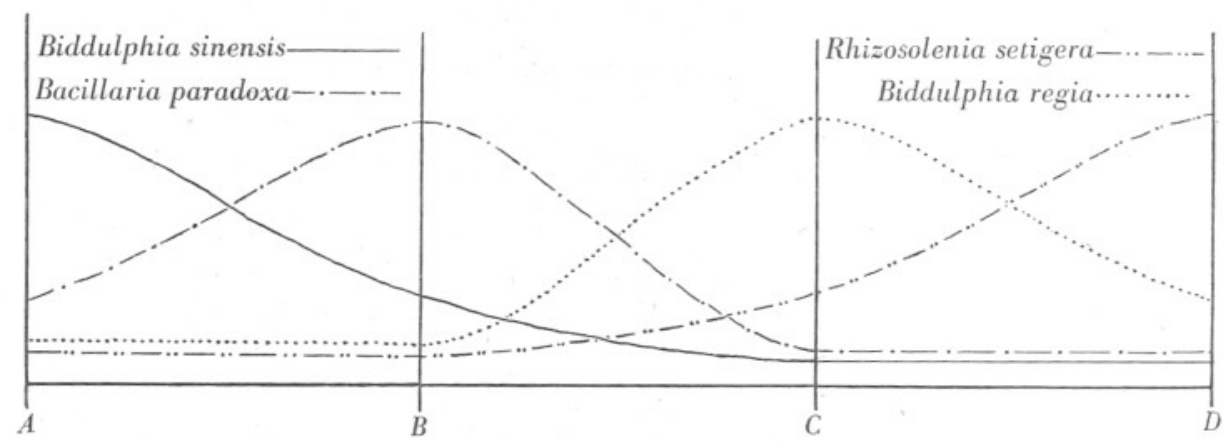

Fig. I2. Diagrammatic representation of the arrangement of the diatoms. See text.

the annual cyclical movement. In this it agreed with Biddulphia sinensis, which decreased from November onwards, and was, therefore, also independent of the annual cyclical movement. It should be noticed that, provided the idea of the annual cyclical movement is true, the decrease in Bacillaria was more extensive than the figures indicate. Since it was during the whole period a down-channel form, Bacillaria should have increased in numbers with the inflow of down-channel water, in agreement with the extension of the gradient in numbers along the investigated length (Fig. 5). That the decrease in Bacillaria cannot be considered as a change dependent on space does not deny the possibility that the annual cyclical movement was largely concerned in the change from $A B$ to $C D$. The succession shown in the copepods would be expected to have its counterpart in the diatoms.

While it is recognized that the section $B C$ is hypothetical, it is considered that the sudden increase of Rhizosolenia setigera on April $25\left(\mathrm{~F}_{1 \mathrm{~g}}\right.$. 5) does not necessarily deny the possibility of a continuous change from $A B$ to $C D$. Such sudden changes in numbers of some species occurred on occasions without corresponding changes in associated forms. Eurytemora decreased suddenly on May 27 and Acartia increased on May 2I (Table X), Podon 
polyphemoides and ascidian larvae appeared suddenly on June I8, post-larval asteroids and ascidian larvae were found on September 26 (Table XII) and Rhizosolenia increased in numbers again on July I9 (Figs. 5, 6).

The consideration of the extent of phytoplankton production involves both a consideration of the actual density of the population and the variations in production throughout the year. On the first question the centrifuge counts (Fig. 8) clearly indicate a marked poverty. The maximum number of 72 chains per 20 c.c. may be compared with the frequent numbers of over 10,000 per 20 c.c. of Marshall \& Orr (1927) and Steeman Nielsen (1935).

The second question is complicated by the cyclical movement, and it is necessary to neglect space and consider chiefly time. In so far as the results

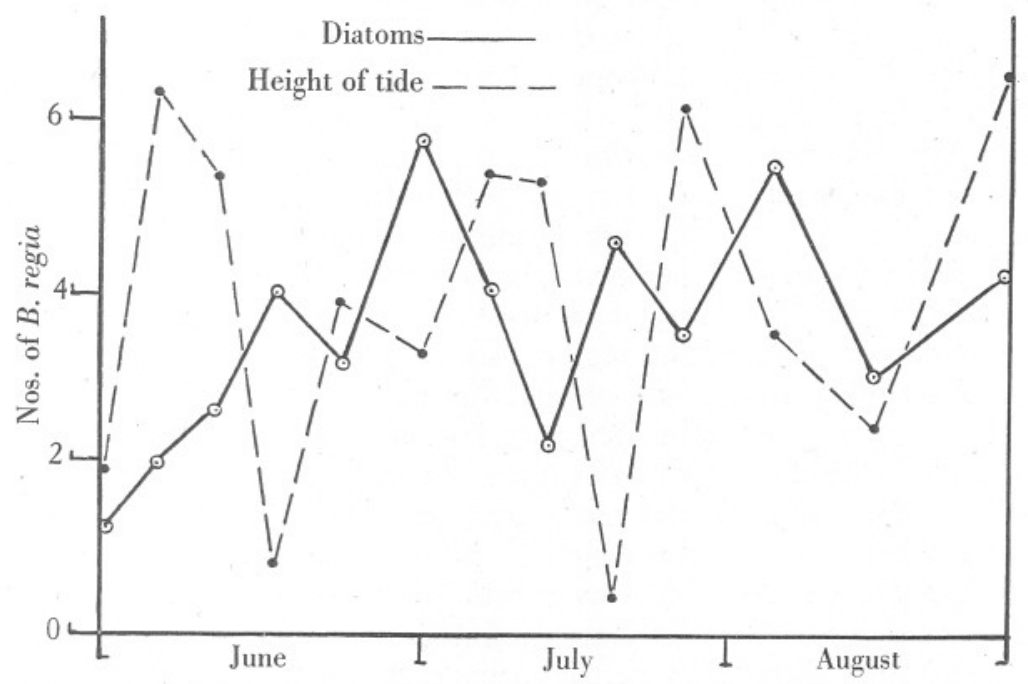

Fig. 13. The relation between the height of tide and the number of Biddulphia regia to one Bacillaria paradoxa chain in the samples from June 3 to August 25.

from samples can be accepted, it appears from Table VIII and Fig. 4 that there was no spring maximum, and that, though there was an increase in numbers from January onwards, there was no sudden rise such as usually occurs in other areas. It is, of course, clear that, because of the annual cyclical movement, the amount of production cannot be deduced from such factors as the phosphate, as was done in general terms by Hardy (1935) and in detail by Harvey (1934b).

The major inhibiting factor on the phytoplankton production must be considered to be the instability of the water which is caused by the tidal streams. Since Gran's (I93I) insistence on the importance of this factor, a considerable body of work has accumulated illustrating this. We may select as examples Steeman Nielsen (1935) and Hart (1934). The action of this factor is to remove the diatoms away from the photosynthetic zone into a 
deeper zone, where photosynthesis cannot take place, thus giving the diatoms less time for effective assimilation. The results of Steeman Nielsen (1935) are particularly striking. He found, for example (p. 70), that the spring increase occurred a month earlier in the stable Icelandic fjords than in the open coastal water, and production begins here only when the water is stabilized.

Owing to the shallowness of the Bristol Channel in the area concerned, instability in itself is not a sufficient explanation, since what is really effective is the ratio between the depth of the photosynthetic zone and the depth of swirling of the diatoms. Arising from the instability is the excessive quantity of silt and detritus in suspension, and it is this that makes the photosynthetic zone into a small layer and so increases the ratio. As it is the ratio which is effective, the conditions of production down-channel are not necessarily better than up-channel, in spite of the gradient of transparency, since farther down-channel the water is deeper. The gradient of decreasing phosphate must also be kept in mind.

The phytoplankton production is, therefore, largely controlled by the opacity, a factor which, in itself, has received much emphasis (Marshall \& Orr, 1928; Pettersson, Höglund \& Landberg, 1934), and the instability. These restrictions on production may be taken as approximately constant throughout the year. The nutritive salts, or, at least the phosphates and by implication the nitrates, were not limiting factors at any time, and, as far as the data go, light appears to be controlling within the limits imposed by the instability. An increase in the amount of light gave rise to an increase of photosynthesis, but, since the effectiveness of the light was reduced by the instability, the increase in photosynthesis did not correspond in degree with the increase of light. The absence of a limiting effect by the nutritive salts permitted the increased photosynthesis, such as it was, to proceed through the summer months and so give a form of diatom numbers shown in Fig. 4.

A contributory factor may be the salinity. Since the diatoms are typically marine, the lower the salinity the greater is the deviation of the environment from normal, but, while this may itself restrict production, the chief effect, probably, is to restrict the number of species and to debar species which might otherwise engage in a sudden increase. The suspended material may restrict certain species and this, possibly, partially accounts for the poverty in the number of species, particularly in the zooplankton. Ostenfeld (I93I) maintains that the absence of several organisms in the eastern part of the English Channel and southernmost North Sea is due to this cause.

It would appear that the causes of the poverty of the fauna and flora in the plankton is due to the instability, with resulting siltiness, and the low salinity. The bacteriological examination of the water indicates sewage pollution, but, since the oxygen saturation is not appreciably lowered, it is unlikely that this pollution acts as an inhibitory factor. Sewage pollution may, in fact, favour plankton production. Välikangas (1926) has found that in the harbour of Helsingfors the greatest production of plankton takes place in the Bay of 
Tölö where the greatest amount of sewage from the town of Helsingfors is poured out.

A note on the quantitative method may not be out of place. The poverty of the phytoplankton and the amount of suspended matter present considerable difficulties. Analyses of small samples of water, as in the centrifuge and sedimentation processes, would not give results of the type such as have been here presented, especially as the volume, small as the processes demand, is made smaller by the amount of silt that would be deposited. The silt introduces difficulties, also, in filtration of larger samples of water, since, even with a filter of 100 meshes to the inch, the volume of inanimate matter was usually greater, and often several times greater, than the volume of plankton, with resulting difficulties in the analysis of the samples. The use of a fine filter or phosphorbronze (Hentschel, I936) would therefore defeat its own object, and towing with a very fine net would have a similar result. Possibly the only improvements on the method, as far as present methods go, would be the use of a meter (Harvey, 1934a) or a centrifugal pump (Gibbons \& Fraser, 1937).

It is recognized that the method resulted in a selection of the diatoms, missing out comparative samples of, for example, Skeletonema costatum, and collecting the larger diatoms. However, the majority of the diatoms listed in Table XII would have been caught at least as efficiently as Bacillaria and Rhizosolenia setigera, and an accumulation of these would have given an indication of a sudden rise in numbers had there been one. Gran (1932, p. 346) maintains that "The total sum of all species could not be used to measure the productivity of an area of the sea any better than the study of the growth and decrease of the dominant species". The present discussion on phytoplankton production depends upon this.

\section{ACKNOWLEDGEMENTS}

I take the greatest pleasure in acknowledging my indebtedness to Prof. W. M. Tattersall who has given me the considerable advantages of his personal instruction, help and encouragement in the course of this work and previously. I am also deeply obliged to my present colleagues, $\mathrm{Mr}$ C. E. Lucas and $\mathrm{Mr} \mathrm{N}$. B. Marshall, for affording me ample opportunity for discussing with them, to my great advantage, the various problems arising from the results.

The field and laboratory work was done while I held a Post-graduate Studentship of the University of Wales.

\section{SUMMARY}

The plankton collected at a station in the Bristol Channel in $1936-7$ is related to chemical and hydrographical factors.

On account of the varying speeds of the tidal streams, the observations 
refer, not to a single point, but to a series of points along a length of the channel.

Gradients of salinity, phosphate, and a possible complicated gradient of oxygen saturation, were determined, and, from the average monthly salinities, an annual cyclical movement of water deduced.

From February to June Biddulphia sinensis was a more up-channel form than Bacillaria paradoxa, and, from June to August Biddulphia regia was more up-channel than Rhizosolenia setigera. In this latter period Biddulphia regia was more up-channel than Bacillaria.

From being concentrated at the bottom on the up-channel side Eurytemora became more and more evenly distributed from the surface to the bottom on the down-channel side.

Owing to the annual cyclical movement, a succession of copepod species from up-channel to down-channel entered the investigated length.

The decrease in numbers of Biddulphia sinensis and Bacillaria was, directly, independent of the annual cyclical movement, but this movement may have been effective to some extent in transforming the diatom population.

The instability of the water and the opacity, which result from the tidal streams, are the major inhibiting factors on diatom production. Low salinity and excessive siltiness are possible contributory factors.

Phosphate was not, at any time, a limiting factor, and diatom production was, apparently, controlled by light within the limits imposed by the inhibiting factors.

The bacteria indicate some sewage pollution.

\section{REFERENCES}

Alexander, W. B., Southgate, B. A. \& Bassindale, R., I935. Survey of the river Tees. Part II. The estuary-chemical and biological. Water Pollution Research Tech. Paper, No. 5, i-xiv, pp. I-I7I.

AlsterbuRG, G., I926. Die Winklersche Bestimmungsmethode für im Wasser gelösten Sauerstoff, usw. Biochemische Zeitschrift, Vol. CLxx, pp. 30-75.

AtkINS, W. R. G., I923. The phosphate content of fresh and salt waters in its relationship to the growth of algal plankton. Fourn. Mar. Biol. Assoc., Vol. xIII, pp. II -50.

Dianova, E. \& Voroshilova, A., I935. Salt composition of medium and specificity of marine bacteria. Mikrobiol. (U.S.S.R.), Vol. IV, p. 393.

Fox, C. J. J., I907. The dissolved gases of sea-water. Public. de Circons., No. 4I, pp. $\mathrm{I}-23$.

GibBons, S. G. \& Fraser, J. H., I937. The centrifugal pump and suction hose as a method of collecting plankton samples. Fourn. Cons. Int. Explor. Mer., Vol. xII, No. 2, pp. $155-70$.

Gran, H. H., I93I. On the conditions for the production of plankton in the sea. Rapp. Proc.-Verb. Int. Cons. Explor. Mer., Vol. Lxxv, pp. 37-46.

I932. Phytoplankton. Methods and problems. Fourn. Cons. Int. Explor. Mer., Vol. vII, No. 3, pp. 343-58.

GuRney, R., I93I. British Freshwater Copepods, Vol. I, Ray Soc., pp. I-238. 
Hardy, A. C. \& Gunther, E. R., I935. The plankton of the South Georgia whaling grounds and adjacent waters, I926-1927. Discovery Reports, Vol. XI, pp. I-456.

HaRT, T. J., I934. On the phytoplankton of the south-west Atlantic and the Bellinghausen Sea, I929-I931. Discovery Reports, Vol. viII, pp. I-268.

Harvey, H. W., I934a. Measurement of phytoplankton population. Fourn. Mar. Biol. Assoc., Vol. xIx, pp. 76I-73.

- I934b. Annual variation of planktonic vegetation, 1933. Fourn. Mar. Biol. Assoc., Vol. xIX, pp. 775-92.

Hentschel, E., 1936. Zur quantitativen Planktonmethodik. Kieler Meeresforsch., Bd. I, pp. 322-6.

Jorgensen, O. M., 1929. Plankton of the river Tyne estuary. Proc. Univ. Durham Phil. Soc., Vol. viII, pt. I.

Lloyd, B., I930. Bacteria of the Clyde Sea area. A quantitative investigation. Fourn. Mar. Biol. Assoc., Vol. xvI, pp. 879-907.

Marshall, S. M. \& OrR, A. P., I927. The relation of the plankton to some chemical and physical factors in the Clyde Sea area. Fourn. Mar. Biol. Assoc., Vol. xiv, pp. $837-68$.

- 1928. The photosynthesis of diatom cultures in the sea. Fourn. Mar. Biol. Assoc., Vol. xv, pp. 321-60.

MCCLEndon, J. F., I9I7. The standardization of a new colorimetric method for the determination of hydrogen-ion concentration, etc., of sea water. Fourn. Biol. Chem., Vol. 30, pp. 265-88.

Meek, A., I923a. Estuarine plankton. Dove Mar. Lab. Report for 1923, pp. 78-91.

Meek, E. M., I923b. Pollution in the river Tyne. Dove Mar. Lab. Report for I923, pp. $53-66$.

MINISTRY OF HEALTH, I936. The bacteriological examination of water supplies. Reports on Public Health and Medical Subjects, No. 7I.

Nielsen, E. Steeman, 1935. The production of phytoplankton at the Faroe Isles, Iceland, East Greenland and the waters around. Medd. Komm. Danmarks Fisk.- og Havunders, Ser. Plankton, Vol. II I, Nr. I, pp. I-93.

Ostenfeld, C. H., I93I. Résumés des observations sur le plankton des Mers explorées par le Conseil pendant les années 1902-8. Cons. Perm. Int. Expl. Mer. Bull. Trim., Pt. 4.

Percival, E., I929. A report on the fauna of the estuaries of the river Tamar and the river Lynher. Fourn. Mar. Biol. Assoc., Vol. xvI, pp. 8I-I08.

Pettersson, H., Höglund, H. \& Landberg, S., I934. Submarine daylight and the photosynthesis of phytoplankton. Göteborg Vetensk. Samh. Handl., 5. B, Bd. 4 (5), pp. I-I7.

RUSSELL, F. S., 1936. A review of some aspects of zooplankton research. Rapp. Proc.-Verb. Cons. Int. Explor. Mer., Vol. xcv, pp. 3-30.

VäLIKANGAS, I., I926. Planktologische Untersuchungen im Hafengebiet von Helsingfors. I. Ueber das Plankton insbesondere das Netz-Zooplankton des Sommerhalbjahres. Helsingforsiae I926. Acta Zoologica Fennica, I, pp. I-298.

Wells, A. L., 1938. Some notes on the plankton of the Thames estuary. Fourn. Animal Ecol., Vol. vir, pp. I05-24.

Wilson, D. P., I929. The larvae of the British Sabellarians. Fourn. Mar. Biol. Assoc., Vol. xvI, pp. 221-5I. 